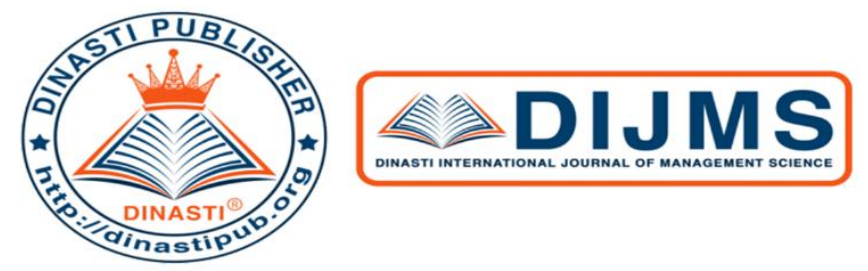

$+6281387654578$

+6281387654578 (Q)

https://dinastipub.org/DIJMS (4)

dinasti-info@gmail.com @

\title{
APPLICATION OF AHP FOR SUPPLIER SELECTION IN CONSTRUCTION COMPANIES
}

\author{
Rosalendro Eddy Nugroho', Maria Sherly Iskandar ${ }^{2)}$ \\ ${ }^{1)}$ Postgraduate Lecturer, Mercu Buana University, Jakarta, Indonesia \\ ${ }^{2)}$ Postgraduate Student, Mercu Buana University, Jakarta, Indonesia
}

\begin{tabular}{|c|c|}
\hline $\begin{array}{c}\text { ARTICLE INFORMATION } \\
\text { Received: } 21 \text { st April } 2020 \\
\text { Revised: } 29^{\text {th }} \text { May } 2020 \\
\text { Issued: } 19^{\text {th }} \text { July } 2020 \\
\text { Corresponding author: Maria } \\
\text { Sherly Iskandar } \\
\text { E-mail: } \\
\text { rosalendro.eddy@ mercubuana.ac.id } \\
\text { mariasherlyiskandar@gmail.com }\end{array}$ & $\begin{array}{l}\text { Abstract: The procurement process is an important } \\
\text { process in supply chain management as it is the spearhead } \\
\text { of the entire process. In carrying out the procurement } \\
\text { process, there are often problems with the supplier } \\
\text { selection activities. This is because the supplier selection } \\
\text { process spends a lot of time and resources collecting data } \\
\text { and conducting careful analysis that will affect the entire } \\
\text { decision alternative. In making decisions relating to the } \\
\text { many criteria and the number of alternative suppliers, it } \\
\text { requires an effective and uncomplex assessment technique, } \\
\text { but it provides accurate results. A mapping and } \\
\text { determination of supplier selection criteria is required as a } \\
\text { basis for valuation to obtain a qualified supplier. This study } \\
\text { focused on PT. XYZ is a construction company in South } \\
\text { Tangerang. Analytical Hierarchy Process (AHP) is used to } \\
\text { determine the best supplier, there are } 4 \text { variables that are } \\
\text { reference in conducting the selection of suppliers, such as: } \\
\text { cost, quality, delivery, and service. The result in the } \\
\text { selection of the supplier company is cost with a weight of } \\
0.268 \text {, quality with a weight of } 0.290 \text {, delivery with a } \\
\text { weighting of } 0.248 \text {, and the service with a weight of } 0.194 \\
\text { where conclusions obtained from the analysis of the } \\
\text { selection of the best suppliers and in accordance with the } \\
\text { criteria, namely PT. CBL for iron suppliers, PT.SAS for } \\
\text { cement suppliers, and PT. Citra BSD for suppliers of } \\
\text { natural materials.. } \\
\text { Keywords: AHP, supply chain, procurement, supplier } \\
\text { selection. proiect. construction. }\end{array}$ \\
\hline
\end{tabular}

\section{INTRODUCTION}

Procurement is a process to obtain useful goods and services to ensure the smooth production process and logistics of a company. The procurement process is an important process in supply chain management as it is the spearhead of the entire process. In conducting procurement process, there are often problems in the activity of selection of suppliers. This is 
because the supplier selection process spends a lot of time and resources collecting data and conducting careful analysis of the various positive and negative factors that will affect the whole alternative decision [2]. Therefore, it takes methods that can be used to help the supplier selection process. The selection of suppliers needs to consider many criteria, therefore the supplier evaluation process requires a multi-criteria approach in the analysis and retrieval of solutions [4]. Once the criteria are established and some candidates are acquired, the company must make the selection. The company may choose one or more of the existing alternatives. In this election the company may have to do a step to determine which supplier to choose or which will be used as the main supplier and which will be used as a spare supplier. One method that is quite common used in the preferred alternative to the number of criteria is the Analytical Hierarchy Process (AHP). AHP is a decision support method developed to solve problems by breaking down the problem solution, grouping and then putting it into a hierarchical structure. To obtain the prioritized criteria, this method uses a comparison of paired criteria with a predefined measurement scale. The primary Input of the AHP method is the perception of experts or experts, so there is a subjectivity factor in decision making. This method also takes into account the validity of the data by the presence of inconsistency limits [10].

\section{LITERATURE REVIEW \\ Supply Chain Management}

Supply Chain Management (SCM) is not only oriented to the internal affairs of a company, but also external affairs relating to the relationship with the partner companies with an approach integrating the supplier, manufacturer, distribution center, wholesaler, retailer (retailer), and customer, where the product is manufactured and Distributed in correct quantities, precise location and timing to minimize costs and increase customer satisfaction [1]. Because companies that are in a supply chain in essence want to satisfy the consumers of the same end, they must work together to make the product acceptable to the customer, in order to supply chain of goals can be achieved.

SCM can improve the competitive ability for the overall supply chain, but does not cause a long-term sacrifice. It is therefore necessary to clear understanding, belief, and play rules. It is important to maintain ethics for those who want a strong supply chain in the long term.. In the concept of supply chain, suppliers are one of the most important and influential part of the company's life continuity. When we refer to a manufacturing company, the main activities that are included in the SCM classification are:

1. Product development

2. Procurement, purchasing or supply

3. Inventory planning and control

4. Production

5. Distribution

6. Product Return

SCM requires a robust approach and management model to stay in the business world. The above is coupled with various rules or demands in the government and community to maintain the environmental aspects in the supply chain activities. One of the major challenges 
in the management of supply chain is that uncertainty can come from the direction of demand, supplier, or internal company.

The focus of SCM problems should focus on the following:

1. Network configuration distribution: number and location of suppliers, production facilities, distribution centers, warehouses and customers.

2. Distribution strategies: centralization/decentralisation, direct customer, crossanchored, compelling or encouraging strategies, third-party logistics.

3. Information: Integrated systems and processes through supply chains to share valuable information, including demand for signals, forecasts, inventory and transport.

4. Inventory Management: Quantity and location of inventory including raw goods, work processes and finished goods.

5. Fund flow: Set up payment terms and methodology for exchanging funds through entities within the supply chain.

6. Supply chain execution: organizing and coordinating the movement of information materials and funds among the supply.

\section{Procurement}

Procurement management is providing inputs in the form of goods or services needed in production activities or other activities within the company. In manufacturing companies, goods that must be purchased by procurement parts can be classified generally into raw materials production needs, capital equipment such as machinery, and other long-term equipment, machinery parts and stationery office. Along with the increasing demands of the customer and the short of the product life cycle in various sectors of industry, the mixing part is also required to be able to create an advantage in terms of time. As one of the important factors in competing, the time can be very determined whether or not supply chain in the fight in the market.

The general procurement duties include:

1. Designing the right relationships with suppliers. These relationships are longterm partnerships and short-term transactional relationships. The Procurement Section is tasked to design a relationship portfolio for all suppliers.

2. Choosing a supplier. The activity of choosing a supplier can take time and resources not less if the supplier is a key supplier.

3. Choose and implement suitable technology. Procurement activities always require technological assistance. Nowadays, many companies use electronic procurement.

4. Maintain data on required items and supplier data. The Procurement section must have full data on the required items as well as data about the supplier.

5. Make a purchase. This is the most routine work done by the Procurement Section. Purchases can be routinely or through tender or auction.

6. Evaluate supplier performance. This performance assessment is very important to create a sustainable competitiveness. Assessment results can also be used as a supplier input to improve their performance. 


\section{Supplier Selection}

In supply chain management, supplier selection decisions are generally regarded as one of the most significant in the responsibilities of managers [6]. To maintain a competitive edge in global markets, organisations should consider environmental issues and embrace the supplier selection evaluation model. Supplier selection decisions can be applied in many situations such as many supplier cases, as well as in various stages of life cycle products from the initial raw material purchase to the end of the service provider [3].

The main factor considered by a company when choosing a supplier is [13]:

1. Price factors are usually a major factor, whether there is a discount offer, even though it is sometimes not the most important thing.

2. The quality of a company may cost you more to improve the quality of good goods.

3. Special services sometimes can be important in the selection of suppliers. Replacement of damaged goods, instructions for use, repair of equipment and similar services, can be a key in the selection of one supplier than the other.

4. Location of the supplier can have an influence on the delivery time, transportation costs, and response time when there are sudden orders/orders or emergency services. Purchasing in local/local areas can foster goodwill in a relationship and can help the area's economy.

5. Supplier Inventory policy Suppliers if the supplier can maintain its policy and maintain its spare part, it can help in case of sudden raw material needs.

6. The flexibility of good responses and the supplier's ability to respond to changes in demand and meet changes in order design can be an important factor in the selection of suppliers.

The hierarchy is defined as a representation of a complex problem in a multi-level structure, where the first level is the goal followed by the level of factors, criteria, subcriteria, and for the last level of alternatives. With a hierarchy, complex problems can be outlined into groups that are then assigned to form a hierarchy so that problems will appear more structured and systematic. The selection of suppliers in the framework of the supply chain is not much different from the one described above, the main difference is that the suppliers in the framework of the supply chain thinking have a far more important position, become partners and strategic alliances, have long-term relationships, reliable research and product development, and are expected to continuously improve the quality and price of goods. Therefore, research and development should be more complete and thorough, although the determination stage to be a supplier partner can be done through several stages.

\section{Supplier Selection Criteria}

Selection criteria are one of the key things in supplier selection. The criteria used must necessarily reflect the supply chain strategy as well as the characteristics of the items to be supplied. In general, many companies use basic criteria such as the quality of goods offered, prices, and timeliness of delivery. However, often supplier selection requires various other criteria that the company considers important.

Supplier selection decisions should be considered well because suppliers can make an impact on the company, whether it is a positive impact or a negative impact on the company's performance. Therefore, a supplier's selection, management, and evaluation process is 
required. Criterion is one of the factors that can be used in selecting and evaluating Suppliers [8], then the criteria is important to be determined so that the company can choose the best supplier.

Supplier selection plays an important role in the company's supply chain process. Companies must work with different suppliers to perform their activities so that components and spare parts can be delivered on time. Supplier selection is a problem of multi-criterion decision Making (MCDM) [15]. The main factors considered by a company when choosing a supplier are price, quality, service, location, supplier inventory policy and flexibility [13]. There are 22 criteria for supplier selection [5] :

Table 1. Criteria in Supplier Selection

\begin{tabular}{|ll|}
\hline Criteria & Score \\
\hline Quality & 3.5 \\
Delivery & 3.4 \\
Performance History & 3.0 \\
Warranties and Claim Policies & 2.8 \\
Price & 2.8 \\
Technical Capability & 2.8 \\
Financial Position & 2.5 \\
Procedural Compliance & 2.5 \\
Communication System & 2.5 \\
Reputation and Position in Industry & 2.4 \\
Desire for Business & 2.4 \\
Management and Organization & 2.3 \\
Operating Control & 2.2 \\
Repair Service & 2.2 \\
Attitude & 2.1 \\
Impression & 2.1 \\
Packaging Ability & 2.0 \\
Labor Relation & 2.0 \\
Geographical Location & 1.9 \\
Amount of Past Business & 1.6 \\
Training Aids & 1.5 \\
Reciprocal Arrangement & 0.6 \\
\hline
\end{tabular}

(Source: Dickson, 1966; Pujawan, 2017)

\section{Analytical Hierarchy Process}

Analytical Hierarchy Process (AHP) is a method discovered by Saaty [11] [9]. It is a method for ranking several decision alternatives and selecting the best one when the decision maker has multiple objectives, or criteria, on which to base the decision [14]. The AHP is a functional model of the hierarchy with the primary input being human perception. AHP is a decision-making method developed to solve problems by finding solutions to problems, grouping and then putting them into a hierarchical structure. To obtain the prioritized criteria, this method uses a comparison of paired criteria with a predefined measurement scale. The 
primary Input of AHP method is the perception of experts or experts, so there is a subjectivity factor in decision making.

The steps and procedures in resolving the problems that are Kom-Pleks using AHP method are as follows:

1) Defining problems and determining objectives

2) Create a hierarchy

The problem is arranged in a hierarchy that begins with a general purpose, followed by subobjectives, criteria, and possible alternatives at the bottom of the criteria level.

3) Do a comparison pair (pairwise comparison).

The comparison is based on "Judgement" from decision makers by assessing the importance of an element compared to other elements. The comparison matrix can be seen in table 2.4. This matrix illustrates the relative contribution or influence of each element to each of the above objectives or criteria. Where the value of comparison $A_{i}$ against the $A_{j}$ element is $a_{i j}$. $A$ value is determined by the rule:

a) if $\mathrm{a}_{\mathrm{ij}}=\alpha$, then $\mathrm{ji}_{\mathrm{i}}=1 / \alpha, \alpha \neq 0$.

b) If $\mathrm{Ai}$, have the same level of relative importance of $A_{j}$, then $a_{i j}=a_{j i}=1$.

c) The special thing, $a_{i i}$ for all $i$.

Table 2. Pairwise Comparison Matrix

\begin{tabular}{|c|c|c|c|c|}
\hline Criteria & A1 & A2 & $\ldots \ldots$ & An \\
\hline A1 & $\mathrm{a} 11$ & $\mathrm{a} 12$ & $\ldots \ldots$ & $\mathrm{a} 1 \mathrm{n}$ \\
\hline $\mathrm{A} 2$ & $\mathrm{a} 21$ & $\mathrm{a} 22$ & $\ldots \ldots$ & $\mathrm{a} 2 \mathrm{n}$ \\
\hline$\ldots$. & $\ldots \ldots$ & $\ldots \ldots$ & $\ldots$. \\
\hline An & an1 & an2 & $\ldots \ldots$ & ann \\
\hline & & & & \\
\hline
\end{tabular}

(Source: Saaty, 1994)

The comparison is done until judgement is obtained entirely by $\mathrm{n} X[(\mathrm{n}-1) / 2]$ pieces, with $n$ being the number of elements being compared.

4) Determining priorities

Priority drafting is done for each element of the problem at the hierarchy level. This process will result in weighting or contributing criteria to achieve the objectives. Priorities are determined by the highest weighted criteria. The desired weight is expressed in the eigen vector $\mathrm{W}=\left(\mathrm{W}_{1}, \mathrm{~W}_{2}, \ldots, \mathrm{W}_{\mathrm{n}}\right)$. The $\mathrm{W}_{\mathrm{n}}$ value stated is the relative weight of the criteria $\mathrm{A}_{\mathrm{n}}$ for the overall set of criteria on sub-systems.

5) Consistency Index (CI) 
$C I=\frac{(\lambda \max -n)}{(n-1)}$

Where :

$\lambda \max =$ largest value of Eigen in matrix order $n$

$\mathrm{n} \quad=$ number of criteria

Consistency Ratio (CR)

$C R=\frac{C I}{R I}$

Where :

$\begin{array}{ll}\mathrm{CI} & =\text { Index Consistency } \\ \mathrm{CR} & =\text { Consistency Ratio } \\ \mathrm{RI} & =\text { Random Index }\end{array}$

Table 3. Random Index (RI)

\begin{tabular}{|c|c|c|c|c|c|c|c|c|c|}
\hline $\mathrm{N}$ & 1 & 2 & 3 & 4 & 5 & 6 & 7 & 8 & 9 \\
\hline $\mathrm{RI}$ & 0 & 0 & 0.58 & 0.9 & 1.12 & 1.24 & 1.32 & 1.41 & 1.45 \\
\hline
\end{tabular}

(Source: Saaty, 1998)

When the pairwise/comparison matrix has a value of CR $<0.10$ then the inconsistency of the opinions of decision makers is acceptable, and if the value is not met then the assessment should be repeated.

Weights for group assessments are stated by finding geometric mean:

$\mathrm{GM}=\sqrt[n]{(x 1) \cdot(x 2) \ldots .(\mathrm{xn})}$

Where :

$$
\begin{array}{ll}
\mathrm{GM} & =\text { Geometric Mean } \\
\mathrm{X}_{1} & =\text { responden } 1 \\
\mathrm{X}_{2} & =\text { responden } 2 \\
\mathrm{Xn} & =\text { responden }-\mathrm{n} \\
\mathrm{n} & =\text { total of responden }
\end{array}
$$

\section{RESEARCH METHODS}

Supported qualitative method because the research is done through field observations with the dissemination of questionnaires and interviews directly on the director of engineering, project manager, supervisor procurement, staff quantity surveyor, and field coordinator, to obtain other important information about the factors used in the selection of suppliers. Meanwhile, there are as many as 7 supplier companies. The criteria used in the selection of suppliers are as follows:

1) Cost, includes 3 sub-criteria : 
(C1) Material Price

(C2) Discount Price

(C3) Payment Deadlines

2) Quality, includes 3 sub-criteria :

(Q1) Accuracy of Material Type

(Q2) Material Strength

(Q3) Ability to Deliver Consistent Quality

3) Delivery, includes 3 sub-criteria :

(D1) Timely Delivery

(D2) Accuracy of Shipment Amount

(D3) Transportation Handling Capability

4) Service, includes 6 sub-criteria :

(S1) Warranty

(S2) Quick Response in Handling Customer Request

(S3) Quick Response to Customer Complaints Handling

(S4) Ability to Provide Product Information Clearly

(S5) Fast and Precise Handling of Material Volume Change Requests

(S6) Fast and Precise Handling Request Change of Material Booking Time

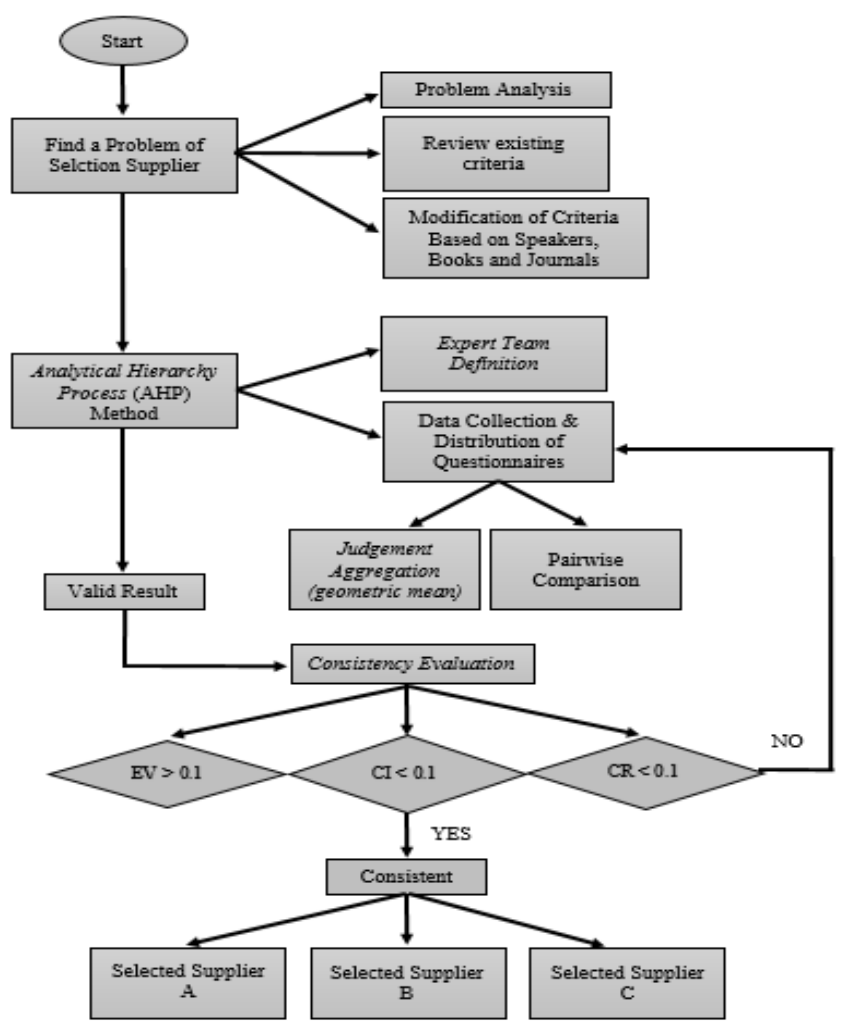

Figure 1. Diagrammatic Representation of the Research Workflow

The non probability sampling technique used in this study is a sampling purposive technique of sampling techniques with certain considerations. The reason the sample selection by using purposive sampling is because not all of the samples have the criteria corresponding to which the authors specify. This is because the AHP method hints at the 
respondent according to the type of specialist concerned in decision making. In addition, respondents must also have sufficient knowledge and experience about the problem. Primary data retrieval is done by completing questionnaire and interview. This is done by spreading the questionnaire, discussion and direct questioning to get the data. And secondary data is derived from data procurement process in XYZ Enterprise system, through the literature on supllier selection, and other previous re-search related to the research.

\section{FINDINGS AND DISCUSSION}

Based on interviews with the Technical Director, Project Manager, Procurement Supervisor, Quantity Surveyor Staff, and Field Coordinator, it was found that all suppliers offer similar prices. This implies that the price criterion is no longer relevant to be used as a basis in selecting suppliers. Based on some historical data, it is agreed that there are four criteria to be used in the selection of suppliers, i.e. cost, quality, delivery, and services.

\section{Structuring the Hierarchy}

This figure shows the hierarchy for the supplier decision model.

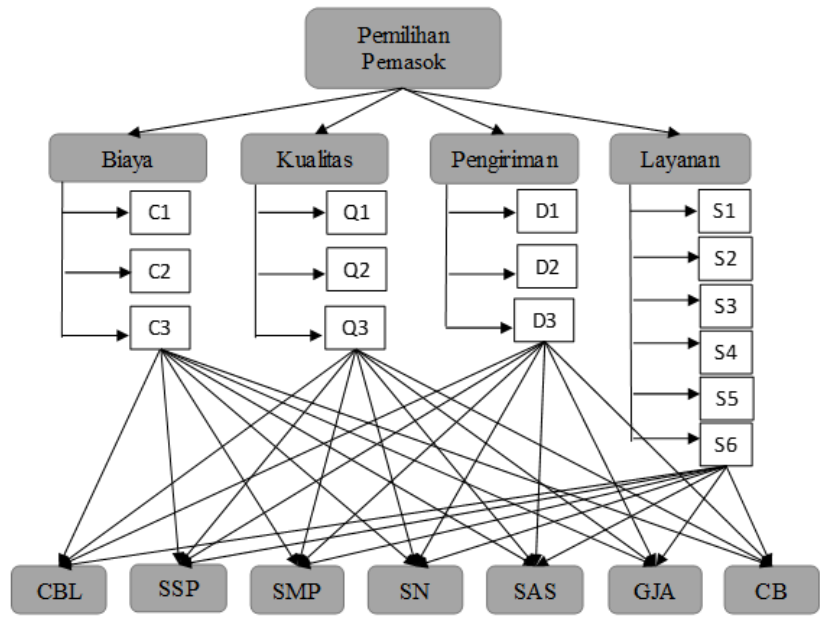

Figure 2. Hierarchical Representation of the AHP Model

\section{Performing Pairwise Comparisons}

After constructing the hierarchy, pairwise comparisons were performed systematically throughout the structure. Prior to our study, we hoped that we would be able to go through the pairwise comparisons together with the decision making team. It was not possible due to differences among the schedule of the managers. Hence, 105 questions questionnaires including all possible pairwise comparison combinations were distributed to the decisionmaking team.

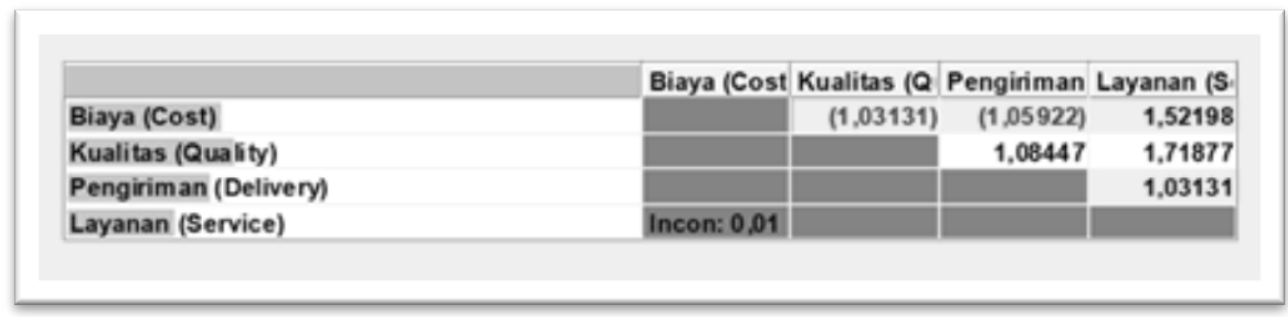


Figure 3. Pairwise Comparison Combinations

Biaya (Cost)

Kualitas (Quality)

Pengiriman (Delivery)

Layanan (Service)

Inconsistency $=0,00954$

with 0 missing judgments.

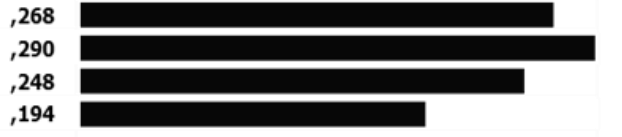

Figure 4. Comparing Major Criteria -Judgments and Resulting Weights of Major Criteria

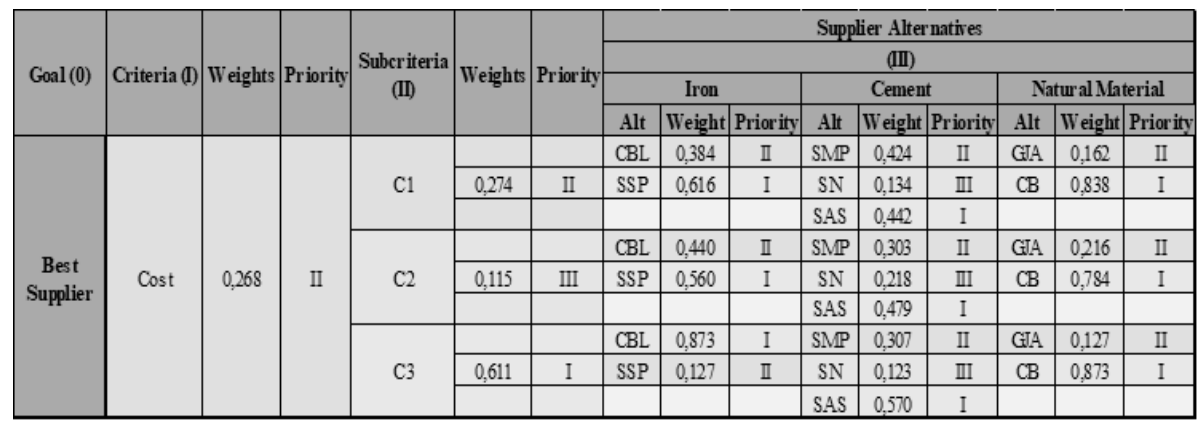

Figure 5. Priorities of Cost Criteria and Alternatives Supplier

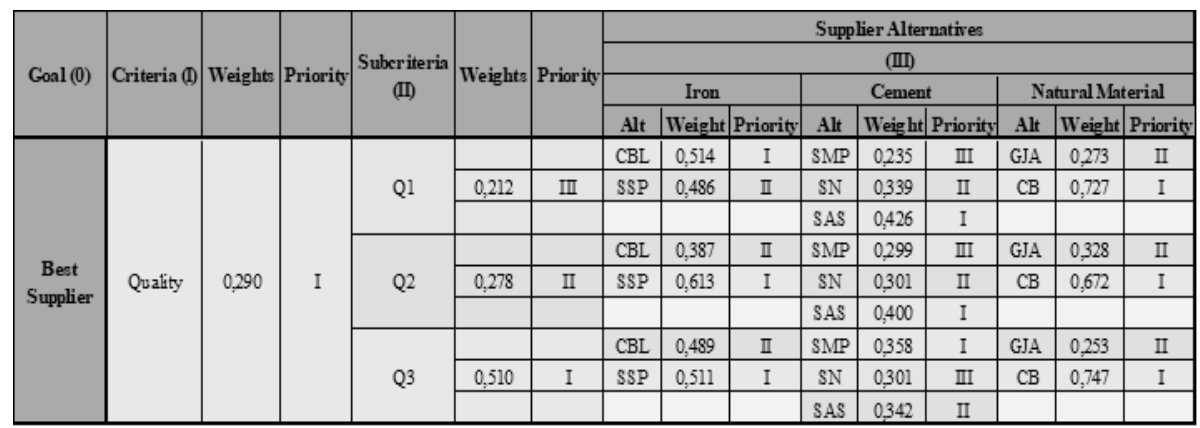

Figure 6. Priorities of Quality Criteria and Alternatives Supplier

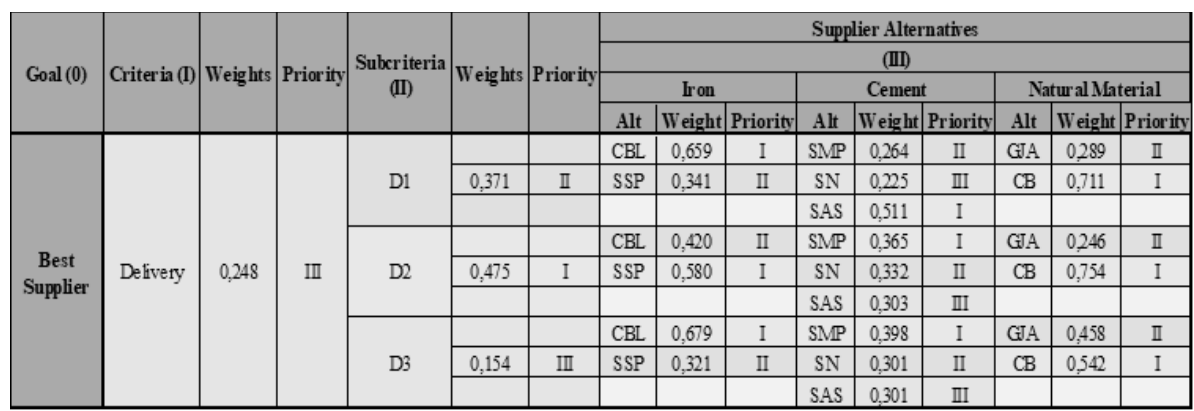

Figure 7. Priorities of Delivery Criteria and Alternatives Supplier 


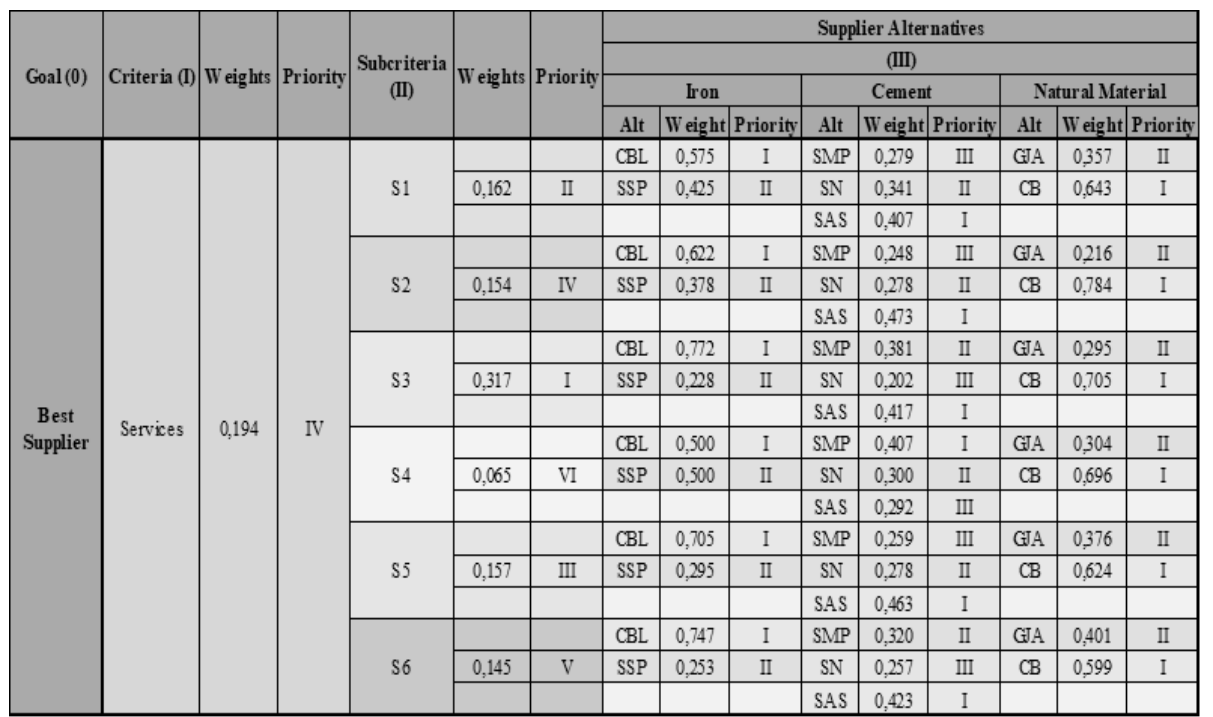

Figure 8. Priorities of Services Criteria and Alternatives Supplier

There are 4 criteria used in this research, the highest weight criteria that can be referenced by the company in choosing the Supplier is quality (weight of interest 29\%), hereinafter the cost (interest 26.8\%), delivery (weight of interest 24.8\%) and services (weight of interest 19.4\%). Data analysis result from AHP calculation, obtained using a questionnaire of 5 respondents, stating that the alternative selection of each main material selected and best according to the criteria, for the iron supplier is PT. Camar Baja Lestari, cement supplier is PT. Sumber Abadi Sukses, and natural material supplier is PT. Citra BSD.

\section{CONCLUSION AND SUGGESTION}

$\mathrm{XYZ}$ companies rely heavily on suppliers for project sustainability, so that no delays are caused by the improper selection of suppliers. To determine some concerns about choosing the right supplier, one of them is using AHP method. Because AHP method is a method by which the main input is human perception As [11] pointed out one major weakness of the application-oriented AHP literature is that it tends to focus on the mechanics of the AHP, instead of the practical implications of implementing the methodology. Selected quality criteria based on the ability to provide consistent quality of each supplier. After that new criteria consider the cost, delivery and service. It is very important to minimize the delay of project completion.

We needed a methodology that was well supported with a well developed software conducive to making a real life application that would be easily understood by the managers. When there are many criteria involved, AHP is among the very few multiple criteria approaches capable of handling them, especially if some of the criteria are qualitative. The Expert Choice software enables sensitivity analysis of the results which is very important in any really practical decision-making process. We were able to obtain the cooperation of the decisionmaking team to structure the model and to get them to make the necessary judgments to solve it. We attribute our success mainly to the ease of use of AHP and the existence of easy-to-use commercial software. In this study the AHP model was used for a strategic supplier selection process, but in addition to effective supplier selection purchasing managers 
can also use this model for supplier benchmarking, supplier development initiatives, and evaluating supplier performance.

\section{REFERENCE}

Akbar, Pri Gustari, Henmaidi, dan Elita Amrina. (2015). Usulan Indikator Evaluasi Pemasok Dalam Penetapan Bidder List : Studi Kasus Pengadaan Jasa PT. Semen Padang. Jurnal Optimasi Sistem Industri. 14 (1), hal.36-49.

Avila, P; Mota A, Pires A, Bastos J, Putnik G, and Teixeira J. (2012). Supplier's Selection Model Based on an Empirical Study. Procedia Technology, Vol.5, pp.625-634.

Bai C and Sarkis J. (2010b). Integrating Sustainability Into Supplier Selection With Grey System and Rough Set Methodologies. International Journal Production Economic, Vol.124, pp.252-264.

Büyüközkan G., Çifçi G., and Güleryüz S. (2011). Strategic Analysis of Healthcare Service Quality Using Fuzzy AHP methodology. Expert Systems with Applications, Vol.38 (8), pp.9407-9424.

Dickson, G W. (1966). An analysis of vendor selection systems and decisions. Journal of Purchasing, Vol.2 (1), pp.5-17.

Golmohammadi D and Mellat-Parast M. (2012). Developing a Grey Based Decision Making Model for Supplier Selection. International Journal Production Economic, Vol.137, pp.191-200.

Handfield, R.B., Walton, S.V., Sroufe, R. \& Melynyk, S.A. (2002). Applying environmental criteria to supplier assessment: a study in the application of the analytical hierarchy process. European Journal of Operational Research, 141: 70-87.

Mirmousaa S and Dehnavib DH. (2016). Development of Criteria of Selecting the Supplier by Using the Fuzzy DEMATEL Method. Procedia-Social and Behavioral Sciences, Vol.230, pp.281-289.

Nydick R., and Hill R. P. (1992). Using the Analytic Hierarchy Process to Structure the Supplier Selection Procedure. International Journal of Purchasing and Materials Management 28 (2): 31-36.

Saaty, T. L. \& Kearns, K. P. (1985). Analytical Planning The Organization of Systems. Pergamon Press.

Saaty, T. L. (1994). Fundamentals of Decision Making and Priority Theory, RWS Publications, Pittsburgh.

Saaty, T.L. (2005). Theory and Applications of the Analytic Network Process: Decision Making with Benefits, Opportunities, Costs, and Risks. RWS Publications, USA.

Stevenson, William J. (2018). Operations Management. McGraw-Hill. New York.

Taylor, B. W. (2010). Introduction to Management Science, 10th ed, Prentice Hall, New Jersey. 
Zhang X; Yong D, Felix TS, Andrew A, and Sankaran M. (2014). "Supplier Selection Based on Evidence Theory and Analytic Network Process". Proceedings of the Institution of Mechanical Engineers, Vol.230 (3), pp.562-573. 